\title{
A tragédia de Flora Emília
}

\section{Vita brevis: a Carta de Flória Emília para Aurélio Agostinho.}

GAARDER, J ostein. Tradução de Pedro Maia Soares.

São Paulo: Companhia das Letras, 1997. $225 \mathrm{p}$.

O autor desse livro, Jostein Gaarder, assegura ter encontrado em um sebo de San Telmo, Buenos Aires, cópia de manuscritos redigidos por Flória Emília, concubina de Aurélio Agostinho, ou seja, um dos pilares da Igreja católica e do pensamento cristão, o bispo de Hipona, predic a dor, ora dor, ca tequiza dor, doutor e santo - Santo Agostinho.

O livro Vita brevis: a carta de Flória Emília para Aurélio Agostinho condensa, em dez capítulos, 70 ou 80 folhas de perga minho, escritas sem paginação, o que tomou a tradução um verdadeiro quebra-cabeça. Foram escritas em um la tim dos tempos vivid os pela suposta autora.

Flória Emília, a o ler as famosas Confissões do bispo, carregadas de "notas sombrias", em que em a penas duas fra ses se referem a ela, sem, todavia, mencionar seu nome, teve o cuidado de instruir-se, para sustentar seus argumentos 
contra os rela tos do ex-a mante convertido. Tomase conhecedora dos Evangelhos, dos filósofos, dos clássicose dos grandes poetas, chegando, com isso, a o posto de professora de Retórica.

Mais de dez anos são passados entre a separação dos amantes e o envio da carta extensiva "a toda a Igreja cristã." Flória Emília tinha sido abandonada e expulsa para a África pelo pai de seu único filho que the foi tirado para nunca mais vê-la. Ela fora trocada por um rival que não era uma mulher, mas sim um princípio filosófico. Segundo suas palavras, um princípio que afetava todas as mulheres, ou seja, o Obitus veneris, isto é, "a a niquilação do a mor".

Aurélio Agostinho, amante dos prazeres sensuais, inicia-se, ainda jovem, inexperiente e desajeitado, nos braços de Flória Emília, a té revelar-se um homem de sensualida de irrefreá vel, segundo ela, "da língua ao dedo médio." Mas, após 12 anos de convivência, ele renuncia a esse a mor tempestuoso, a bandona Flória Emília e leva com ele o filho Adeodato, passando a dedicarse a uma busca alucinada da salvação de sua alma, a que Flória Emília chama de "agonia espiritual". Em nome desse louco a mor ela jurouIhe fidelidade a té o finalda vida, e a té o final da vida recusou-se a ser batizada, alegando não ter tido nunca "visões" nem ouvido "vozes", nem mantido jamais contato com o sobrenatural. Segundo ela, se houver céu acima de tudo, merecerá, por certo, o perdão de Deus, por prender-se ao "físico", recusando-se a crer num Deus que exige sacrifíc ios humanos.

E o "físic o" passa a a tormentar o bispo transtorna do, subitamente tão sério. Torturam-no tanto a memória dos "váriose tenebrososa mores" como os sonhos erótic os, que enlouquecem sua a Ima estimulada por baixas imaginações, desenfreando seus instintos carnais. Aflito, pergunta a Deus, nessesmomentos: "Senhormeu Deus, será que eu já não sou eu?" Flora Emília, serena, dizque não e que talvez ele seja apenas a sombra dele mesmo. Dizque melhor lhe conviria ser um escravo sobre a terra do que um alto sacerdote nesse labirinto de sombras. Ele deseja a morte quotidiana em si mesmo, para tirar-lhe os sentidos, negando a própria vida, a o constatar que "os bens terrenos ta mbém são a gra dá veis e ta mbém têm uma doçura que não é pequena". Ao pensar na felicidade, teme procurá-la; foge dela, quando a vislumbra no "abraço de uma mulher".

Aurélio Agostinho, a fundando-se no la birinto sombrio dos teólogos, gaba-se, diante de Deus, de desprezar o mundo dos sentidos, crendo que tudo o que existe, fora Dele, é obra do diabo.
Flória Emília contesta, interrogando-o, se não se trata exatamente do contrário; se somos seres criados por Deus, não nos cabe viver e usufruir da obra criada por Ele? E o bispo insiste. Chama de "perigo de prazer" o comer e o beber; ao humor, de "concupiscência"; roga a Deus que a voluptuosida de dos olhos não a corrente sua a Ima com a variedade, brilho e luminosida de dascores; vê "peca do" no colorido, no perfume e na beleza das flores, na melodia dos Salmos de Davi, no ato de cheirar ruma flor - tud o inserido na sua lista perpétua de pecados e culpas. Afirma que Deus quero homem em absoluta continência; que não há ninguém diante d'Ele imune ao pecado, nem mesmo o recém-nascido, com a penasum dia de vida; chama o próprio filho de "fruto do pecado", o que a mãe rebate argumentando que "a criança é concebida no amor" e que Deus ordenou o mundo de maneira bela e sábia, não permitindo "que isso acontecesse por gemina ção". Flória Emília, entrando no labińntico raciocínio do bispo, pergunta o que restará a final desse homem e de sua vida aqui na terra; o que é "pecado", o que é "vício"; o que são "coisas vã s", constantes em suas Confissões. Não seria tudo isso, simplesmente, o que os separa de Deus? Ela teme pelo que os homens da Igreja possam fazer às mulheres que não existem senão para tentá-los. Seguind o o percurso turbulento de seus raciocínios, Deus ama os eunucose os castrados, acima daqueles que amam as mulheres. Contradizendo a lógica do bispo, ela indaga se não será estragara obra de Deusum homem não poderabraçar uma mulher; se o Deus que criou o céu e a terra e todas as criaturas, "inclusive mulheres e crianças", não foi o mesmo que criou Vênus. Indaga também se poracaso os teólogos, como os filósofos, teriam permissão para dizer absurdos de toda ordem.

Confusa e insegura quanto à existência de Deus e do etemo, Flória Emília ama a vida, o mundo, o ar, o canto dos pássaros, a abóbada c eleste; crê nos ouvidos e nos olhos criados tão divinamente quanto o sexo; reconhece o ser humano, com direito a usufruir de toda a obra da criação, parecendo a rrogância rejeitá-la, à semelhança dosheróis gregos, e lembra a o bispo que, sem pecar, pode comer e beber quando tem fome e sede, é livre o bastante para cheirar uma flor e não precisa ter vergonha de ser homem.

Aurélio Agostinho vai para Milão, com o objetivo de entrar para o círculo de Ambrósio, agora bispo, mas influente no Estado, onde ocupara alto cargo. Ao conhecê-lo, o futuro santo, minucioso no cuidado da salvação de sua a lma 
e no desprezo por todas as coisas do mundo, julga-o afortunado, por ser um homem "homenageado pelos poderosos".

Seu amante Aurel não the deixou clara a expressão "a vida é breve" que muitas vezes lhe repetiu, mas Flória Emília tem opiniões próprias sobre sua brevidade e importância. A vida é breve, diz ela, e sabemos muito pouco. Nada nos a ponta uma etemidade certa para nossas a Imas frágeis. No entanto, somos livres para ter esperança de uma vida após esta e não há tempo para julgaro amor. Certamente se referia a o tom condenatório dos teólogos, os qua is ela verdadeiramente temia, a cima do Filho de Deus que, quando passou pela terra, foi justo para com as mulheres.

Aurélio Agostinho odiava-se por não ser suficientemente miserável, achando que isso é que agrada a Deus. Cita sua semoções violentas após a conversão. Certa vez, quando severas reflexões expuseram toda a sua miséria, desencadeou-se-lhe uma torrente de lágrimas, que jorravam de seus olhos aos borbotões, e refugiou-se, a pressado, debaixo de uma figueira, para ali oferecê-las a Deus como um "sacrifício agradável".

Quando o bispo tece elogios sobre a bela a miza de entre homens com sina is "que brota va $m$ de corações que amam e se sentem amadose que se manifestam no procedimento, nas palavras, no olhar e em mil gestos de agradecimento, como centelhas que inflamam muitos corações e deles fazem um só", Flória Emília se sente "comida e regurgitada" ao mesmo tempo. Pergunta, lendo esse trecho das Confissões, se não era também amizade verdadeira o que ela lhe oferecera durante aqueles tantos anos de convivência, no procedimento, nas doces palavras, tantas vezes trocadas, nos olhares e nas melhores coisas que vivera $m$ em conjunto. Teria sido esse o tempo em que ele mais longe estava de Deus? Incrédula, completa que, se existe um Deus, Ele registrou, certamente, toda a generosidade que se deram e, se não existe, ninguém, em todo o universo, conhecerá o outro melhor que a mbos. E Aurélio Agostinho, agora, tudo a niquila com sua frieza advinda dos maniqueus e dos platônicos, tudo resume em "pecado de concupiscência".

Ainda em companhia de Flória Emília, quando nem padre era, Aurel fic ou doente e teve medo de morrer. Medo porque, explicou-se depois, nas Confissões, vivendo em tal comportamento, ou seja, em concubinato mesmo sendo costume da época os homens terem concubinas antes do casamento -, iria para o fogo e para aspenas estabelecidas pela lei de Deus. Flória Emília espanta-se com a leitura das crenças do ex-companheiro, a medrontado por esse Deus da Ira, que pune, a tormenta e leva as pessoas para o infemo, por toda a etemidade. Tomam, igualmente, esse destino os que também nã o consentem ser batiza dos.

Flória Emília acusa gravemente Mônica, mãe de Aurel, de tê-los separa do, para substituíla por uma outra mulher mais a propriada. Mas essa mulher tinha a penas 11 anos e era preciso esperar mais dois, segundo a lei, para a idade matrimonial. Flória Emília, no entanto, se pergunta se o futuro da família estava sendo realmente preserva do com esse casamento de a lta posição social, ou se Mônic a tinha ciúmes do filho. Houve uma primavera, ela se recorda, em que essa mãe fora correndo para Milão, quando os a mantes lá se encontravam, para se pôrentre elese, com o tempo, acabou vencendo o duelo. Essa mãe parece ter roubado a o filho a vontade de amar uma mulher. Flória Emília chega a falar sobre a ligação de a mbos "porlaçosque não são natura is entre mãe e filho."

Depois da morte de Mônica, o vazio que Aurélio Agostinho sentiu foi tão grande que, com a alma despedaçada e sangrando, escreveu uma carta para Flória Emília, em um vai-e-vem mítico-filosófic o: "Como sinto tua falta, Flória! Gostaria que estivesses conosco a gora. Quero te ver, quero e, a o mesmo tempo, não quero te ver. Quero, masnão posso, e nã o posso, mas te veria". Flória Emília interpretou essas palavras como querendo vê-la e viajou para Roma, onde puderam abraçar-se novamente durante algumas semanas. Mas Mônica, que ocupava o lugar de Deus na vida do filho, deixou Deus no lugardela. 0 bispo estava em desespero, tal qual Édipo e seu destino absurd o. Flória Emília sugereIhe a castração, em vez de arrancar os olhos como a personagem de Sófocles.

Porém, foi em uma tarde fatídic a que tudo terminou. Depois de terem compartilhado momentos de muita temura, Aurélio Agostinho, tomado de uma raiva súbita, açoita violentamente sua parceira, em uma perversidade mórbida, como se estivesse despedaçando Eva, nome que, eventualmente, Ihe dava, para, em seguida, de joelhos, chorando, de mãos postas, implorarperdão, ora para ela, ora para Deus, ama rrando, ele mesmo, com panos, seus ferimentos, confortando-a.

Logo em seguida manda-a de volta para Cartago, para nunca ma is se verem, nem mesmo pela ocasião da morte do filho Adeodato. 
Aurélio Agostinho silencia em suas Confissões sobre esse gravíssimo episódio que Flória Emília nomeia de "último a to da tragédia". No esforço tão grande que fez para escrevê-las, o bispo suplica que Deus aceite as inumeráveis coisas que deixa em silênc io e de outras ma is de que não se recorda. Em silêncio, pois parece impossível ter se esquecido, deixa igualmente o a mor sensual pela concubina, porque, segundo a redatora dessa carta, ele põe um limite nas suas Confissões, pois delas não constam suas faltas mais graves.

Foi assim que Flória Emília sepa rou-se de seu Aurel, homem que vivia constantemente "exposto ao pecado", em luta permanente contra as "tentações da carne", escraviza do por uma guerra quotidiana de "jejuns" e "mortificações", e ta mbém o homem que teve vergonha de chorar a morte da mãe, por ser a dor um sentimento terreno; que deixou de amar, de apreciar a comida, de cheirar as flores, de escutar o canto dos Salmos, para se afundar em um fanático e histérico encontro com Deus.

Ela conclui que, se Deus realmente existe, poderá, em a lgum lugar, condená-lo porter da do as costas a todas as alegrias da vida, o que, seguramente, não derivou dos ensinamentos do Nazareno.

Muitos séculos depois, Volta ire, o irreverente irreligioso do lluminismo, repetiria Flória Emília, na crític a sobre Les Pensées de Pascal, a fimando que "a natureza estabeleceu que cada homem desfrute do presente, alimentando-se, fazendo filhos, ouvindo sons agradáveis" e que não renegue $o$ instinto que Deus lhe deu, "fazendo dele o uso para o qualé destinado". O pensador cético, recomenda ainda, em uma lúcida lição de fé: "Adoremos Deus sem querer penetrar na obsc uridade de seus mistérios".

Heloísa Corrêa Moura Universidade de São Paulo 